\title{
SIFAT PENGKARATAN LIMA JENIS KAYU YANG DISIMPAN DI TEMPAT TERBUKA TERHADAP BESI
}

\section{(Corrosion Properties on Five Wood Species in an Open Site to Iron)}

\author{
$\mathrm{Oleh} / \mathrm{By}$ : \\ Djarwanto \\ Email: djarwanto2006@yahoo.com \\ ${ }^{1}$ Pusat Penelitian dan Pengembangan Keteknikan Kehutanan \\ dan Pengolahan Hasil Hutan \\ Jl. Gunung Batu No. 5, Bogor, Telp. 0251-8633378, Fax. 0251-8633413
}

Diterima 24 Januari 2011, disetujui 28 Juni 2011

\begin{abstract}
Five wood species i.e. Litsea roxburghii Hassk. (tangkalak), Erythrina fusca Lour. (cangkring), Melaleuca cajuputi Powell (kayu putib), Zanthoxylum rhetsa D.C. (ki tanab) and Sterculia cordata (Blume) BL. (buru leueur) originated from Ciamis and Tasikmalaya were evaluated their corrosiveness to iron metal screw in an open site exposed to sunshine and rain. Wood samples were divided radially into three groups, namely outer, middle and inner part of logs. The corrosion properties were identified by the weight loss of the attached metal screws. Results showed that iron corrosion was found in all over tested wood species. Rust discoloration was obtained on 2 weeks after exposing. The corrosion intensities were obtained by the variation of weight loss. Highest corrosion rates was found on samples of kayu putih. The highest weight loss of screw was found on kayu putih samples extracted from outer part log of tree P-II (A part), i.e. 5.96\%. The lowest weight loss of screw was encountered on huru leueur samples extracted from outer part of tree P-II(A part), i.e. 0.04\%.
\end{abstract}

Keywords : Metal screw, wood, rust discoloration, iron corrosion, weight loss

\section{ABSTRAK}

Lima jenis kayu yang berasal dari Kabupaten Ciamis dan Tasikmalaya yaitu Litsea roxburghii Hassk. (tangkalak), Erythrina fusca Lour. (cangkring), Melaleuca cajuputi Powell (kayu putih), Zanthoxylum rhetsa D.C. (ki tanah) and Sterculia cordata (Blume) BL. (huru leueur) di uji sifat pengkaratannya terhadap sekrup logam di tempat terbuka. Contoh uji diambil dari bagian tepi (A), tengah (B), dan dalam (C) dolok. Sifat pengkaratan ditunjukkan dari besarnya kehilangan berat sekrup. Hasilnya menunjukkan bahwa pengkaratan besi terjadi pada semua jenis kayu yang diuji. Pelunturan warna karat sekrup telah terjadi pada umur 2 minggu setelah pemasangan. Tingkat pengkaratan ditunjukkan oleh variasi besarnya kehilangan berat sekrup. Sifat korosif logam yang besar umumnya terjadi pada kayu putih. Kehilangan berat sekrup 
tertinggi didapatkan pada kayu putih yang berasal dari pohon P-II bagian tepi (A) yaitu 5,96\%. Sedangkan kehilangan berat sekrup terendah terjadi pada kayu huru leueur dari pohon P-II bagian tepi (A) yaitu $0.04 \%$.

Kata kunci : Sekrup logam, kayu, pelunturan karat, pengkaratan besi, kehilangan berat

\section{PENDAHULUAN}

Untuk mendirikan bangunan umumnya masih digunakan logam seperti paku, sekrup dan engsel. Apabila logam tersebut berikatan dengan kayu yang dipasang di tempat terbuka (terkena hujan dan panas) maka akan mengalami pengkaratan, yang ditunjukkan dengan adanya bercak warna coklat pada kepala (pentolan) sekrup atau pelunturan warna coklat atau warna lainnya pada permukaan kayu di sekitar logam tersebut. Menurut Nawawi (2002) kerusakan logam pada kayu dapat terjadi melalui proses pengkaratan. Pengkaratan tersebut terjadi secara kontak langsung antara kayu dengan logam atau kayu yang dipasang berdekatan dengan logam. Noda akibat pelunturan warna karat logam dapat terjadi pada semua jenis kayu mulai dari samarsamar hingga coklat gelap atau abu-abu gelap (Djarwanto, 2009). Informasi mengenai sifat pengkaratan logam yang berikatan pada kayu masih sangat sedikit. Oleh karena itu diteliti sifat pengkaratan logam yang berikatan pada kayu di tempat terbuka. Penelitian dilakukan dengan tujuan untuk mengetahui sifat pengkaratan sekrup logam yang dipasang pada 5 jenis kayu asal Ciamis dan Tasikmalaya kemudian disimpan di tempat terbuka.

\section{BAHAN DAN METODE}

\section{A. Bahan dan Alat}

Bahan yang digunakan dalam penelitian ini adalah 5 jenis kayu yang berasal dari Kabupaten Ciamis dan Tasikmalaya, Provinsi Jawa Barat (Tabel 1). Adapun bahan kimia yang digunakan yaitu asam chlorida $(\mathrm{HCl})$ teknis, asam sulfat $\left(\mathrm{H}_{2} \mathrm{SO}_{4}\right)$, alkohol teknis dan aceton. 
Tabel 1. Jenis kayu yang diuji terhadap sekrup logam Table 1. Wood species tested with metal screws

\begin{tabular}{|c|l|l|l|}
\hline No & \multicolumn{1}{|c|}{$\begin{array}{c}\text { Jenis kayu } \\
\text { (Wood species) }\end{array}$} & $\begin{array}{c}\text { Nama daerah } \\
\text { (Local name) }\end{array}$ & \multicolumn{1}{|c|}{$\begin{array}{c}\text { Suku } \\
\text { (Family) }\end{array}$} \\
\hline 1 & Litsea roxburghii Hassk. & Tangkalak & Lauraceae \\
\hline 2 & Erythrina fusca Lour. & Cangkring & Leguminoceae \\
\hline 3 & Melaleuca cajuputi Powell & Kayu putih & Myrtaceae \\
\hline 4 & Zanthoxylum rhetsa D.C. & Ki tanah & Rutaceae \\
\hline 5 & Sterculia cordata (Blume) BL. & Huru leueur & Sterculiaceae \\
\hline
\end{tabular}

\section{B. Metode}

Dolok lima jenis kayu tersebut digergaji dibuat papan, dikering anginkan dan selanjutnya dibuat contoh uji dengan ukuran penampang $2,5 \mathrm{~cm} \times 1,5 \mathrm{~cm}$ dan panjang 5 $\mathrm{cm}$ searah serat. Pola pengambilan contoh uji seperti disajikan pada Gambar 1, yaitu bagian tepi (A) pada posisi $4 \mathrm{~cm}$ dari arah kulit luar), bagian tengah (B) pada posisi di antara bagian tepi dan bagian dalam) dan bagian dalam (C) pada posisi $2 \mathrm{~cm}$ dari titik pusat diameter (empulur).

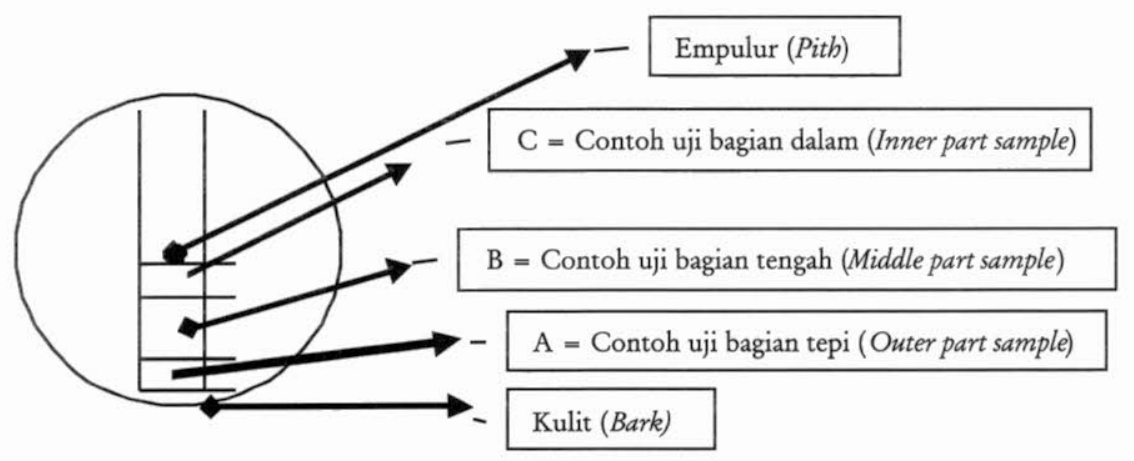

Gambar 1. Pola pengambilan contoh uji Figure 1. Cutting pattern of wood samples 
Contoh uji yang telah diketahui berat kering mutlaknya, dibiarkan kering udara. Pada setiap contoh uji dipasang sekrup besi di bagian tengah, kemudian disimpan di atas kawat anyaman tahan karat di tempat terbuka dan dibiarkan terkena panas dan hujan selama 3 bulan (16 Desember 2009 - 15 Maret 2010). Untuk setiap jenis kayu, perlakuan pohon dan bagian kayu masing-masing disediakan 5 buah contoh uji. Pengamatan dilakukan setiap minggu untuk mengetahui pelunturan warna sekrup pada kayu dan pengkaratan pada kepala sekrup. Pada akhir percobaan sekrup dikeluarkan dari contoh uji kemudian dicelupkan ke dalam $\mathrm{HCl}$ teknis, dibersihkan secara hati-hati menggunakan sikat nilon halus dengan larutan alkohol 96\% dan aceton (2:1), dibiarkan kering dan selanjutnya ditimbang (Kadir dan Barly, 1974; Rushelia dan Djarwanto, 2002; Djarwanto, 2009). Penilaian adanya pengkaratan didasarkan pada kehilangan berat sekrup. Selain itu, contoh uji kayu yang telah dikeringkan dengan oven $105^{\circ} \mathrm{C} \mathrm{juga}$ ditimbang untuk mengetahui kehilangan beratnya. Contoh kayu tersebut diketukketuk secara hati-hati untuk membersihkan bubuk karat yang kemungkinan tertinggal di dalam lubang bekas sekrup. Apabila terdapat sekrup yang patah di dalam contoh uji maka kayu tersebut dibelah secara hati-hati untuk mengeluarkan sekrupnya. Kehilangan berat sekrup dan kayu dihitung berdasarkan selisih berat kering sebelum dan sesudah perlakuan dibagi berat awalnya dan dinyatakan dalam persen. Sedangkan kadar air dihitung berdasarkan selisih berat basah pada akhir percobaan dan sesudah kering oven dibagi berat basah yang dinyatakan dalam persen. Kelunturan atau pewarnaan di permukaan contoh uji kayu dan pewarnaan di kepala sekrup akibat pengkaratan diamati secara visual dan diklasifikasikan berdasarkan skala penampilan warna sebagai berikut:

- = tidak terdapat pewarnaan

$+=$ pewarnaan sedikit disekitar sekrup

$++=$ pewarnaan sedang

$+++=$ pewarnaan agak luas

$++++=$ pewarnaan luas

\section{A. Analisa Data}

Data persentase kehilangan berat kayu dan sekrup masing-masing perlakuan di analisa menggunakan rancangan faktorial $5 \times 2 \times 3$ (jenis kayu, pohon contoh dan bagian kayu), dengan lima kali ulangan (Steel dan Torrie, 1993). Jika terjadi perbedaan yang nyata, pengujian dilanjutkan dengan menggunakan prosedur Tukey.

\section{HASIL DAN PEMBAHASAN}

Hasil pengamatan menunjukkan bahwa terjadi serangan jamur (Monilia sp., blue stain dan mold) pada contoh uji setelah disimpan selama satu minggu di tempat terbuka. 
Hal ini disebabkan karena kayu menjadi lembab setelah hujan mulai turun pada hari ke tiga. Pelunturan warna pada kayu mulai terlihat setelah disimpan selama 11 hari. Pada minggu ke dua telah terjadi pelunturan warna di permukaan kayu sekitar sekrup pada semua jenis kayu yang diteliti. Intensitas pewarnaannya tercantum pada Tabel 2, intensitas pewarnaan tersebut meningkat pada minggu ke empat, dan pada minggu selanjutnya tidak tampak lagi adanya perubahan warna tersebut. Pada minggu ke lima, pengkaratan pada kepala sekrup yang dipasang pada semua jenis kayu telah berubah warna dari coklat menjadi kehitaman. Pada kayu huru leueur tidak dijumpai pewarnaan karena hanya 2 dari 5 contoh yang terdapat pelunturan sedikit. Dijumpai retak sepanjang contoh, pada 5 contoh uji kayu putih dari pohon I (P-I) pada bagian tengah (B) dan dalam (C) pada umur 2 minggu. Pada minggu ke empat dijumpai retak pada 6 contoh dari P-I dan 3 contoh dari P-II. Hal ini mungkin disebabkan karena adanya perbedaan panas dan hujan yang mencolok.

Sekrup yang dipasang pada masing-masing jenis kayu di tempat terbuka mengalami kerusakan yang berbeda-beda. Kerusakan sekrup tersebut dapat ditandai oleh adanya pewarnaan kayu akibat pelunturan karat dan pengkaratan kepala sekrup, seperti disajikan pada Tabel 2. Pada semua jenis kayu yang diuji menunjukkan adanya pelunturan warna coklat atau hijau kehitaman pada permukaan kayu, sedangkan pengkaratan pada kepala sekrup berwarna coklat. Pengkaratan sekrup tersebut terjadi karena kayu menjadi lembab dan zat ekstraktif yang bersifat asam bereaksi dengan besi yang merupakan bahan dasar sekrup. Dari beberapa penelitian ditemukan adanya pelunturan warna kecoklatan atau warna kehitaman pada kayu di sekitar sekrup sebagai hasil reaksi pengkaratan logam pada kayu (Djarwanto, 2009). Hal ini didukung oleh pendapat William dan Knaebe (2002), bahwa pelunturan warna tersebut disebabkan oleh reaksi kimia antara zat ekstraktif dengan logam.

Sifat korosif kayu terlihat beragam seperti ditunjukkan oleh besarnya kehilangan berat sekrup yang berikatan dengan kayu (Tabel 3). Krilov (1987) menyatakan bahwa kehilangan berat baja bervariasi pada beberapa jenis kayu. Dinyatakan bahwa keasaman kayu meningkat oleh adanya oksidasi zat ekstraktif dan degradasi hidrolitik dari komponen kayu (Nawawi, 2002). Kehilangan berat sekrup tertinggi dijumpai pada contoh uji kayu putih bagian dalam (A) dari pohon II yaitu 5,96\%, kemudian dari bagian tengah (B) pohon I yaitu 5,62\%. Hal ini mungkin disebabkan oleh kandungan zat ekstraktif yang terdapat pada contoh uji tersebut sehingga sifat pengkaratannya cenderung hebat. Menurut Williams dan Knaebe (2002) kayu yang memiliki kandungan zat ekstraktif besar akan mudah menimbulkan karat pada besi. Reaksi antara zat ekstraktif dengan besi kemungkinan mengakibatkan sebagian kayu yang bersinggungan dengan sekrup terhidrolisis sehingga terjadi pengurangan berat pada kayu tersebut. Menurut Krilov (1986) terjadinya karat pada besi disebabkan karena adanya zat ekstraktif yang sangat kompleks. Zat ekstraktif terdiri dari berbagai senyawa yang sifatnya reaktif, seperti asam organik dan bahan-bahan polifenol dimana beberapa diantaranya dapat membentuk organometallic complexes. Organometallic complexes 
inilah yang menyebabkan terjadinya reaksi pengkaratan antara kayu dengan besi tersebut.

Data kehilangan berat kayu yang berikatan dengan sekrup tersebut juga bervariasi (Tabel 3). Kehilangan berat kayu ini mungkin disebabkan oleh proses oksidasi bersamaan dengan proses pengkaratan. Sedangkan kehilangan berat kayu tertinggi dijumpai pada bagian dalam (C) dari pohon I kayu tangkalak yaitu 16,31\%, kemudian dari pohon II yaitu $14,07 \%$. Ini mungkin disebabkan karena di tempat terbuka kayu terdegradasi oleh pengaruh cuaca (panas dan hujan) serta adanya serangan jamur.

Data rata-rata kadar air contoh uji pada akhir percobaan disajikan pada Tabel 3. Pada kadar air tersebut yaitu 11,77-46,45\%, jamur perusak masih dapat tumbuh dan dapat mengakibatkan kayu menjadi lapuk. Menurut Schmidt (2007) bahwa kadar air optimum untuk pertumbuhan jamur pelapuk berkisar antara 36-210\%.

Hasil analisis statistik menunjukkan bahwa jenis kayu, pohon contoh dan posisi bagian kayu dalam dolok berpengaruh nyata pada kehilangan berat sekrup maupun kayu $(\mathrm{p} \leq 0.01)$. Didapatkan interaksi yang nyata antara jenis kayu, pohon contoh dan posisi bagian kayu dalam dolok terhadap kehilangan berat sekrup $(\mathrm{p} \leq 0.05)$. Menurut Krilov (1987), terjadi interaksi yang nyata antara jenis kayu dan jenis baja. Hasil uji beda Tukey $(\mathrm{p}<0.05)$ terhadap interaksi antara jenis kayu dan posisi bagian kayu dalam dolok menunjukkan bahwa persentase kehilangan berat kayu tertinggi dijumpai pada contoh uji kayu tangkalak yang diambil dari bagian dalam yaitu $16,31 \%$, dan kehilangan berat kayu terendah terjadi pada kayu putih dari bagian tepi $\log (1,47 \%)$.

Hasil uji beda Tukey terhadap jenis kayu $(\mathrm{p}<0.05)$ menunjukkan bahwa kehilangan berat sekrup tertinggi dijumpai pada kayu putih (3,76\%) diikuti oleh kayu tangkalak (1,51\%), sedangkan kehilangan berat sekrup terendah terjadi pada kayu huru leueur adalah 0,34\% (Tabel 4). Menurut Pari (2010) kandungan zat ekstraktif larut air panas pada kayu putih terendah yaitu 4,06\%, dan pada kayu leuer tertinggi $(7,02 \%)$, serta pada kayu tangkalak, ki tanah dan cangkring masing-masing 5,32\%, 4,67\% dan 4,53\% (Tabel 4). Hal ini menunjukkan bahwa kandungan zat ektraktif tidak selalu mempengaruhi intensitas pengkaratan sekrup. Kehilangan berat sekrup pada contoh uji dari pohon P-I $(1,43 \%)$ hampir sama dibandingkan dengan pada contoh dari pohon P-II $(1,49 \%)$. Hasil uji beda Tukey $(\mathrm{p}<0.05)$ terhadap bagian kayu menunjukkan bahwa kehilangan berat sekrup terendah terjadi pada contoh uji bagian dalam $(\mathrm{C})$ yaitu $1,16 \%$, sedangkan bagian tepi (A) 1,60\% dan bagian tengah (B) 1,62\% tidak menunjukkan perbedaan yang nyata. Hasil uji secara laboratoris, kehilangan berat sekrup dari bagian tepi ke bagian dalam cenderung meningkat yaitu 5,93\% (A); 7,13\% (B) dan 7,72\% (C) (Djarwanto, 2009). 
Tabel 2. Pelunturan karat pada kepala sekrup dan permukaan kayu Table 2. Rust discoloration on head of screw and wood surface

\begin{tabular}{|c|c|c|c|c|c|c|}
\hline \multirow[t]{2}{*}{$\begin{array}{c}\text { Jenis kayu } \\
\text { (Wood species) }\end{array}$} & \multirow[t]{2}{*}{$\begin{array}{l}\text { Pohon } \\
\text { conto } \\
\mathrm{h} \\
\text { (Sampl } \\
\text { e tree) }\end{array}$} & \multirow[t]{2}{*}{$\begin{array}{l}\text { Bagian } \\
\text { kayu } \\
(\text { Part of } \\
\text { log) }\end{array}$} & \multicolumn{2}{|c|}{$\begin{array}{c}\text { Pelunturan warna } \\
\text { logam pada permukaan } \\
\text { kayu (Metal } \\
\text { discoloration on wood } \\
\text { surface) }\end{array}$} & \multicolumn{2}{|c|}{$\begin{array}{l}\text { Pelunturan warna } \\
\text { logam pada kepala } \\
\text { sekrup (Metal } \\
\text { discoloration on bead of } \\
\text { screw) }\end{array}$} \\
\hline & & & $\begin{array}{c}2 \text { minggu } \\
\text { (Weeks) }\end{array}$ & $\begin{array}{l}4 \text { minggu } \\
\text { (Weeks) }\end{array}$ & $\begin{array}{c}2 \text { minggu } \\
\text { (Weeks) }\end{array}$ & $\begin{array}{l}4 \text { minggu } \\
\text { (Weeks) }\end{array}$ \\
\hline \multirow{6}{*}{$\begin{array}{l}\text { Tangkalak } \\
\text { (Litsea } \\
\text { roxburghii.) }\end{array}$} & \multirow[t]{3}{*}{ P-I } & $\bar{A}$ & ++ & ++ & ++ & +++ \\
\hline & & B & ++ & ++ & ++ & +++ \\
\hline & & $\mathrm{C}$ & ++ & ++ & ++ & ++ \\
\hline & \multirow[t]{3}{*}{ P-II } & $\mathrm{A}$ & ++ & ++ & + & ++ \\
\hline & & B & + & ++ & + & ++ \\
\hline & & $\mathrm{C}$ & + & ++ & + & +++ \\
\hline \multirow{6}{*}{$\begin{array}{l}\text { Cangkring } \\
\text { (Erythrina } \\
\text { fusca) }\end{array}$} & \multirow[t]{3}{*}{ P-I } & $\mathrm{A}$ & + & ++ & + & +++ \\
\hline & & B & + & + & + & ++ \\
\hline & & $\mathrm{C}$ & + & ++ & - & +++ \\
\hline & \multirow[t]{3}{*}{ P-II } & A & + & + & + & ++ \\
\hline & & $\mathrm{B}$ & ++ & ++ & + & +++ \\
\hline & & $\mathrm{C}$ & + & ++ & ++ & +++ \\
\hline \multirow{6}{*}{$\begin{array}{l}\text { Kayu putih } \\
\text { (Melaleuca } \\
\text { cajuputi) }\end{array}$} & \multirow[t]{3}{*}{ P-I } & $\mathrm{A}$ & ++ & ++ & +++ & ++++ \\
\hline & & $\mathrm{B}$ & +++ & +++ & +++ & ++++ \\
\hline & & $\mathrm{C}$ & +++ & +++ & +++ & ++++ \\
\hline & \multirow[t]{3}{*}{ P-II } & A & ++ & +++ & +++ & ++++ \\
\hline & & B & ++ & +++ & +++ & ++++ \\
\hline & & $\mathrm{C}$ & +++ & +++ & +++ & ++++ \\
\hline \multirow{6}{*}{$\begin{array}{l}\text { Ki tanah } \\
\text { (Zanthoxylum } \\
\text { rbetsa) }\end{array}$} & \multirow[t]{3}{*}{ P-I } & A & ++ & ++ & ++ & ++++ \\
\hline & & $\mathrm{B}$ & ++ & ++ & ++ & ++++ \\
\hline & & $\mathrm{C}$ & + & + & ++ & ++++ \\
\hline & \multirow[t]{3}{*}{ P-II } & A & ++ & ++ & +++ & ++++ \\
\hline & & $\mathrm{B}$ & ++ & ++ & ++ & ++++ \\
\hline & & $\mathrm{C}$ & ++ & ++ & ++ & ++++ \\
\hline \multirow{6}{*}{$\begin{array}{l}\text { Huru leueur } \\
\text { (Sterculia } \\
\text { cordatd) }\end{array}$} & \multirow[t]{3}{*}{ P-I } & $\mathrm{A}$ & + & + & - & +++ \\
\hline & & B & - & + & + & ++++ \\
\hline & & $\mathrm{C}$ & - & + & - & ++++ \\
\hline & \multirow[t]{3}{*}{ P-II } & $\mathrm{A}$ & + & + & + & ++++ \\
\hline & & $B$ & ++ & ++ & ++ & +++ \\
\hline & & $\mathrm{C}$ & ++ & ++ & ++ & ++++ \\
\hline
\end{tabular}

Keterangan (Remarks): $\mathrm{A}=$ Contoh uji bagian tepi (outer part sample), $\mathrm{B}=$ Contoh uji bagian tengah (middle part of sample), C = Contoh uji bagian dalam (inner part of sample), data rata-rata dari lima ulangan (represent average of five replications): $+=$ pewarnaan sedikit disekitar sekrup (slight discoloration around the screw $),++=$ pewarnaan sedang (moderate discoloration), $+++=$ pewarnaan agak luas (rather widespread discoloration),$++++=$ pewarnaan luas (widespread discoloration), - = tidak terdapat pewarnaan (nodiscoloration). 
Tabel 3. Kehilangan berat sekrup yang berikatan dengan kayu

Table 3. Weight loss of screw associated with wood

\begin{tabular}{|c|c|c|c|c|c|}
\hline \multirow{2}{*}{$\begin{array}{c}\text { Jenis kayu } \\
\text { (Wood } \\
\text { species) }\end{array}$} & \multirow{2}{*}{$\begin{array}{l}\text { Pohon } \\
\text { contoh } \\
\text { (Sample } \\
\text { tree) }\end{array}$} & \multirow{2}{*}{$\begin{array}{l}\text { Bagian } \\
\text { kayu } \\
\text { (Part of } \\
\text { log) }\end{array}$} & \multicolumn{2}{|c|}{$\begin{array}{c}\text { Kehilangan berat (Weight } \\
\text { loss), } \%\end{array}$} & \multirow{2}{*}{$\begin{array}{c}\text { Kadar air kayu } \\
\text { (Moisture } \\
\text { content of } \\
\text { wood), \% }\end{array}$} \\
\hline & & & $\begin{array}{l}\text { Sekrup } \\
\text { (Screw) }\end{array}$ & $\begin{array}{l}\text { Kayu } \\
(\text { Wood })\end{array}$ & \\
\hline \multirow{6}{*}{$\begin{array}{l}\text { Tangkalak } \\
\text { (Litsed } \\
\text { roxburgbii.) }\end{array}$} & \multirow[t]{3}{*}{ P-I } & A & 2,15 bcdef & 10,01 & $28,79 \pm 4,92$ \\
\hline & & B & 1,69 bcdefgh & 12,55 & $37,95+8,03$ \\
\hline & & C & 1,93 bcdefgh & 16,31 & $46,45+5,39$ \\
\hline & \multirow[t]{3}{*}{ P-II } & A & 1,72 bcdefgh & 10,41 & $27,72+3,31$ \\
\hline & & B & $0,78 \mathrm{efgh}$ & 10,40 & $30,33+3,85$ \\
\hline & & C & $0,76 \mathrm{efgh}$ & 14,07 & $20,90+6,23$ \\
\hline \multirow{6}{*}{$\begin{array}{l}\text { Cangkring } \\
\text { (Erytbrina } \\
\text { fusca) }\end{array}$} & \multirow[t]{3}{*}{ P-I } & A & 0,80 efgh & 9,10 & $30,76+5,93$ \\
\hline & & B & $1,57 \mathrm{efgh}$ & 9,91 & $40,30+6,61$ \\
\hline & & C & $0,59 \mathrm{efgh}$ & 9,65 & $40,24+1,22$ \\
\hline & \multirow[t]{3}{*}{ P-II } & $\mathrm{A}$ & $0,48 \mathrm{efgh}$ & 12,72 & $45,90 \pm 4,50$ \\
\hline & & B & 1,73 bcdefgh & 12,08 & $41,28+4,56$ \\
\hline & & C & $0,22 \mathrm{gh}$ & 11,67 & $40,86+3,15$ \\
\hline \multirow{6}{*}{$\begin{array}{l}\text { Kayu putih } \\
\text { (Melaleuca } \\
\text { cajuputi) }\end{array}$} & \multirow[t]{3}{*}{ P-I } & A & 2,32 bcde & 1,61 & $12,37+0,85$ \\
\hline & & B & $5,62 \mathrm{a}$ & 1,58 & $13,60+1,43$ \\
\hline & & C & $3,48 \mathrm{bc}$ & 2,18 & $13,06+1,08$ \\
\hline & \multirow[t]{3}{*}{ P-II } & A & $5,96 \mathrm{a}$ & 1,47 & $12,46+1,44$ \\
\hline & & B & 1,59 defgh & 1,74 & $11,77+1,29$ \\
\hline & & C & $3,59 \mathrm{bc}$ & 1,52 & $12,38 \pm 0,44$ \\
\hline \multirow{6}{*}{$\begin{array}{l}\text { Ki tanah } \\
\text { (Zanthoxylu } \\
m \text { rhetsa) }\end{array}$} & \multirow[t]{3}{*}{ P-I } & A & $0,35 \mathrm{fgh}$ & 1,98 & $11,95+0,75$ \\
\hline & & B & $0,11 \mathrm{gh}$ & 2,12 & $12,30+0,55$ \\
\hline & & C & $0,31 \mathrm{fgh}$ & 1,84 & $12,26+0,16$ \\
\hline & \multirow[t]{3}{*}{ P-II } & A & 1,95 bcdefg & 3,45 & $14,41+2,48$ \\
\hline & & B & 1,67 defgh & 2,06 & $12,49+0,68$ \\
\hline & & C & $0,39 \mathrm{fgh}$ & 1,84 & $12,37+0,29$ \\
\hline \multirow{6}{*}{$\begin{array}{l}\text { Huru leueur } \\
\text { (Sterculia } \\
\text { cordata) }\end{array}$} & \multirow[t]{3}{*}{ P-I } & A & $0,18 \mathrm{gh}$ & 6,40 & $20,13+3,08$ \\
\hline & & B & $0,27 \mathrm{fgh}$ & 9,20 & $12,59+2,74$ \\
\hline & & C & $0,08 \mathrm{gh}$ & 6,71 & $25,43+4,36$ \\
\hline & \multirow[t]{3}{*}{ P-II } & $\mathrm{A}$ & $0,04 \mathrm{~h}$ & 7,17 & $13,18+1,94$ \\
\hline & & B & $1,16 \mathrm{efgh}$ & 6,00 & $11,91+0,55$ \\
\hline & & C & $0,29 \mathrm{fgh}$ & 8,54 & $23,64+6,88$ \\
\hline
\end{tabular}

Keterangan (Remarks): $\mathrm{A}=$ Contoh uji bagian tepi (Outer part sample), B = Contoh uji bagian tengah (Middle part sample), C = Contoh uji bagian dalam (Innerpart of sample), data pengurangan berat (\%) rata-rata dari lima ulangan (the weight loss data (\%) represent average of five replications), $\pm=$ Standar deviasi (Standard deviation data), angka-angka dalam masing-masing kolom yang diikuti oleh huruf sama tidak berbeda nyata pada uji Tukey, $\mathrm{p} \leq 0.05$ (Numbers within each column followed by the same letter, means not-significant difference, Tukey test $p \leq 0.05$ ). 
Tabel 4. Rata-rata kehilangan berat sekrup yang berikatan dengan kayu Table 4. Average weight loss of screw associated with wood

\begin{tabular}{|c|c|c|c|c|c|c|c|}
\hline \multirow{2}{*}{$\begin{array}{l}\text { Jenis kayu } \\
\text { (Wood } \\
\text { species) }\end{array}$} & \multirow{2}{*}{$\begin{array}{c}\text { Pohon } \\
\text { contoh } \\
\text { (Sample } \\
\text { tree) }\end{array}$} & \multirow{2}{*}{$\begin{array}{l}\text { Dia- } \\
\text { meter } \\
\text { dolok } \\
(\mathrm{cm})\end{array}$} & \multicolumn{4}{|c|}{ Kehilangan berat (Weight loss), \% } & \multirow{2}{*}{$\begin{array}{c}\text { Kandungan } \\
\text { ekstraktif } \\
\text { (Extractive } \\
\text { content)*, \% }\end{array}$} \\
\hline & & & $\begin{array}{l}\text { Kayu } \\
\text { (Wood) }\end{array}$ & $\begin{array}{l}\text { Rata-rata } \\
\text { (Average) }\end{array}$ & $\begin{array}{l}\text { Sekrup } \\
\text { (Screw) }\end{array}$ & $\begin{array}{l}\text { Rata-rata } \\
\text { (Average) }\end{array}$ & \\
\hline \multirow{2}{*}{$\begin{array}{l}\text { Tangkalak } \\
\text { (Litsea } \\
\text { roxburgbii.) }\end{array}$} & P-I & 45,2 & 12,92 & \multirow[t]{2}{*}{$12,27 \mathrm{a}$} & $1,92 \mathrm{~b}$ & \multirow[t]{2}{*}{$1,51 \mathrm{~b}$} & \multirow[t]{2}{*}{5,32} \\
\hline & P-II & 45,0 & 11,63 & & $1,09 \mathrm{bcd}$ & & \\
\hline \multirow{2}{*}{$\begin{array}{l}\text { Cangkring } \\
\text { (Erytbrina } \\
\text { fusca) }\end{array}$} & P-I & 40,0 & 9,55 & \multirow[t]{2}{*}{$10,86 \mathrm{~b}$} & 1,00 cde & \multirow[t]{2}{*}{$0,90 \mathrm{c}$} & \multirow[t]{2}{*}{4,52} \\
\hline & P-II & 36,0 & 12,16 & & 0,81 cde & & \\
\hline \multirow{2}{*}{$\begin{array}{l}\text { Kayu putih } \\
\text { (Melaleuca } \\
\text { cajuputi) }\end{array}$} & P-I & 43,5 & 1,79 & \multirow[t]{2}{*}{$1,68 \mathrm{~d}$} & $3,81 \mathrm{a}$ & \multirow[t]{2}{*}{$3,76 \mathrm{a}$} & \multirow[t]{2}{*}{4,06} \\
\hline & P-II & 43,0 & 1,58 & & $3,71 \mathrm{a}$ & & \\
\hline \multirow{2}{*}{$\begin{array}{c}\text { Ki tanah } \\
\text { (Zantboxylum } \\
\text { rhetsa) }\end{array}$} & P-I & 27,5 & 1,98 & \multirow[t]{2}{*}{$2,21 \mathrm{~d}$} & $0,26 \mathrm{de}$ & \multirow[t]{2}{*}{$0.80 \mathrm{~cd}$} & \multirow[t]{2}{*}{4,67} \\
\hline & P-II & 27,0 & 2,45 & & $1,34 \mathrm{bc}$ & & \\
\hline \multirow{2}{*}{\begin{tabular}{|c} 
Huru leueur \\
(Sterculia \\
cordata)
\end{tabular}} & P-I & 25,3 & 7,44 & \multirow[t]{2}{*}{$7,34 \mathrm{c}$} & $0,18 \mathrm{e}$ & \multirow[t]{2}{*}{$0,34 \mathrm{~d}$} & \multirow[t]{2}{*}{7,02} \\
\hline & P-II & 22,4 & 7,24 & & 0,50 cde & & \\
\hline
\end{tabular}

Keterangan (Remarks): Angka-angka dalam masing-masing kolom yang diikuti oleh huruf sama tidak berbeda nyata pada uji Tukey $\mathrm{p} \leq 0.05$ (Numbers within each column followed by the same letter, means not-significant difference, Tukey test $p \leq 0.05)$,

* = Kandungan ekstraktif larut air panas (Pari, 2010).

Hasil uji beda Tukey $(\mathrm{p}<0.05)$ menunjukkan bahwa rata-rata kehilangan berat kayu tertinggi dijumpai pada kayu tangkalak $(12,27 \%)$, sedangkan kehilangan berat kayu terendah terjadi pada kayu putih (Tabel 4). Kehilangan berat kayu dari pohon P-I (6,74\%) lebih rendah dibandingkan dengan pohon P-II (7,01\%), meskipun tidak menunjukkan perbedaan yang nyata $(\mathrm{P} \leq 0.05)$. Kehilangan berat kayu terendah pada contoh uji tepi (A) yaitu 6,42\%; sedangkan kehilangan berat kayu tertinggi bagian dalam (C) 7,43\%, sedangkan kehilangan berat pada kayu bagian tengah (B) $6,76 \%$ yang tidak menunjukkan perbedaan yang nyata dengan bagian tepi $A$ dan dalam (C) $(\mathrm{p} \leq 0.05)$.

\section{KESIMPULAN}

Jenis kayu yang diuji memiliki sifat karat terhadap logam (sekrup). Pelunturan karat telah terjadi pada umur 2 minggu pemasangan di tempat terbuka. Sifat 
pengkaratan yang kuat terjadi pada kayu putih. Derajat pengkaratan sekrup ditunjukkan oleh besarnya kehilangan berat. Semakin tinggi kehilangan berat sekrup menunjukkan sifat pengkaratan kayu semakin kuat. Kehilangan berat sekrup tertinggi dijumpai pada kayu putih yang berasal dari pohon P-II bagian tepi (A) yaitu 5,96\%. Sedangkan kehilangan berat sekrup terendah terjadi pada kayu huru leueur dari pohon P-II bagian tepi (A) yaitu 0,04\%.

Semua contoh kayu yang diuji mengalami kehilangan berat. Kehilangan berat kayu tertinggi didapatkan pada bagian dalam (C) dari pohon P-I kayu tangkalak yaitu 16,31\%, kemudian dari pohon P-II yaitu 14,07\%.

\section{DAFTAR PUSTAKA}

Djarwanto. 2009. Sifat pengkaratan besi pada lima jenis kayu asal Sukabumi. Jurnal Penelitian Hasil Hutan 27 (3): 280-289. Pusat Penelitian dan Pengembangan Hasil Hutan. Bogor.

Djarwanto dan S. Suprapti. 2008. Pengaruh pengkaratan logam terhadap pelapukan empat jenis kayu asal Sukabumi. Jurnal Ilmu dan Teknologi Hasil Hutan 1(2): 5559. Fakultas Kehutanan-Institut Pertanian Bogor. Bogor.

Kadir dan Barly. 1974. Catatan mengenai daya korosif beberapa jenis bahan pengawet kayu. Lembaran Penelitian. Lembaga Penelitian Hasil Hutan Bogor.

Krilov, A. 1986. Corrotion and wear sawblade steels. Wood Science and Technology 20:361-368.

Krilov, A. 1987. Corrosive properties of some Eucalypts. Wood Science and Technology 21:211-217.

Nawawi, D.S. 2002. The acidity of five tropical woods and its influence on metal corrosion. Jurnal Teknologi Hasil Hutan XV (2): 18-24. Fakultas KehutananInstitut Pertanian Bogor. Bogor.

Pari, G. 2010. Analisis kimia beberapa jenis kayu kurang dikenal. Manuskrip.

Rushelia, R. dan Djarwanto. 2002. Sifat korosif kayu sungkai (Peronema canescens Jack.) yang diimpregnasi limbah penyepuhan timah. Prosiding Seminar Nasional IV Masyarakat Peneliti Kayu Indonesia (MAPEKI), tanggal 6-9 Agustus 2001 di Samarinda. Hal: V36-V40. Fakultas Kehutanan Universitas Mulawarman. Samarinda.

Schmidt, O. 2007. Indoor Wood-decay Basidiomycetes: damage, causal fungi, physiology, identification and characterization, prevention and control. German Mycologycal Society and Springer. 40p. 
JURNAL Penelitian Hasil Hutan Vol. 29 No. 2, Juni 2011: 104-114

Steel, R.G.D. dan J.H. Torrie. 1993. Prinsip dan Prosedur Statistika suatu pendekatan biometrik. Hal.: 403-425. PT Gramedia Pustaka Utama, Jakarta.

Williams, R.S. and M. Knaebe. 2002. Iron stain on wood. Finisline Forest Products Laboratory. USDA Forest Service, Madison. www.fpl.fs.fed.us. Diakses tanggal, 26 Agustus 2008. 